\title{
Robust monitoring of the Eurasian lynx Lynx lynx in the Slovak Carpathians reveals lower numbers than officially reported
}

\author{
Jakub Kubala, Peter Smolko, Fridolin Zimmermann \\ Robin Rigg, Branislav Tám, Tomáš Ilko, Danilo Foresti \\ Christine Breitenmoser-Würsten, Rudolf Kropil and Urs Breitenmoser
}

\begin{abstract}
The Eurasian lynx Lynx lynx population in the Carpathian Mountains is considered to be one of the best preserved and largest in Europe and hence is a source for past and current reintroduction projects in central Europe. However, its status in Slovakia has been reported to the European Commission on the basis of hunters' reports and expert estimates that have never been validated by a robust scientific approach. We conducted the first camera-trapping surveys to estimate the density of Eurasian lynx in Slovakia by means of spatial capture-recapture models in two reference areas during 2011-2015. We estimated population density per $100 \mathrm{~km}^{2}$ of suitable lynx habitat (posterior SD) as $0.58 \pm \mathrm{SD} 0.13$ independent individuals (adults and subadults) in the Štiavnica Mountains and $0.81 \pm S D 0.29$ in Velká Fatra National Park and surroundings. These are the lowest densities estimated using spatial capture-recapture models so far reported for the species, suggesting the lynx population in Slovakia is below carrying capacity. We suspect that low densities may be attributable to undetected human-caused mortality. Our results imply that official game statistics are substantially overestimated. Moreover, the lynx population in Slovakia may not be at favourable conservation status as required by the EU Habitats Directive. We therefore call for a thorough assessment of the density and trend of the Slovak Carpathian lynx population, and the establishment of a scientifically robust monitoring system.
\end{abstract}

Keywords Camera trapping, capture-recapture, Carpathians, favourable conservation status, Lynx lynx, population density

JAKUB KUBALA* (Corresponding author) Technical University in Zvolen, Faculty of Forestry, Department of Applied Zoology and Wildlife Management, T.G. Masaryka 20, Zvolen 960 53, Slovakia. Email xkubala@tuzvo.sk

Peter Smolko* and Rudolf Kropil Technical University in Zvolen, Slovakia

Fridolin Zimmermann, Danilo Foresti, Christine Breitenmoser-Würsten and URS BReITENMOSER† KORA, Muri, Switzerland

RoBin Rigg Slovak Wildlife Society, Liptovský Hrádok, Slovakia

Branislav Tám Bojnice Zoo, Bojnice, Slovakia

Томе́š Irкo Diana-Carpathian Wildlife Research, Banská Bystrica, Slovakia

*Also at: Diana-Carpathian Wildlife Research, Banská Bystrica, Slovakia $\dagger$ Also at: University of Bern, Centre for Fish and Wildlife Health, Bern, Switzerland

Received 16 November 2016. Revision requested 25 January 2017.

Accepted 2 May 2017. First published online 7 August 2017.

\section{Introduction}

The population of Eurasian lynx Lynx lynx in the 1 Carpathian Mountains is considered to be one of the best preserved and largest in Europe (Kaczensky et al., 2013). It was the source of lynx for several reintroduction projects between the 1960s and the 1990s (Breitenmoser et al., 2000; Breitenmoser \& Breitenmoser-Würsten, 2008). Although some of the re-established populations prospered initially, most of them have since stagnated or even declined, and suffer from inbreeding (BreitenmoserWürsten \& Obexer-Ruff, 2003; Sindičić et al., 2013). Reinforcement is recommended as a genetic remedy to assure their long-term viability (Schnidrig et al., 2016).

Many of the translocated individuals came from Slovakia, which encompasses c. $17 \%$ of the Carpathians and is considered to be a potential source for reinforcements and further reintroductions (Sindičić et al., 2013; Schnidrig et al., 2016). The removal of individuals, even for conservation purposes, requires adequate monitoring of the source population (IUCN/SSC, 2013). Although Slovakia has been a member of the European Union since 2004 and is therefore obliged by Council Directive 92/43/EEC of 21 May 1992 on the conservation of natural habitats and of wild fauna and flora (the Habitats Directive) to monitor, assess and report on the conservation status of protected species, to date there has been no robust monitoring system for large mammals, including the lynx. Reporting to the European Commission has been on the basis of expert estimates of 300-400 lynx in Slovakia, and the population's conservation status is categorized as unfavourable-inadequate (Černecký et al., 2014). In contrast, official game statistics based on hunters' reports estimated there were 1,668 lynx in Slovakia in 2014 (NLC, 2015). In neither case were these official figures validated by a scientific approach.

Population densities can be estimated reliably from various types of data, including telemetry and snow tracking (Breitenmoser \& Breitenmoser-Würsten, 2008). However, camera trapping combined with capture-recapture analysis has become a widely used approach for elusive but individually distinguishable species such as the Eurasian lynx (e.g. Weingarth et al., 2012; Pesenti \& Zimmermann, 2013; Zimmermann et al., 2013; Avgan et al., 2014). To obtain the first robust data from the Carpathian Mountains of 
Slovakia we conducted camera-trapping surveys in two reference areas. The main goals of our study were to (1) apply this methodology in Slovakia to estimate lynx population density by spatial and non-spatial capture-recapture models, (2) compare our results with other estimates of lynx density, and (3) provide baseline data for ongoing lynx monitoring.

\section{Study areas}

We monitored lynx in two contrasting reference areas: Štiavnica Mountains Protected Landscape Area (IUCN Category V), near the periphery of occupied lynx range, and Velká Fatra National Park (IUCN Category II), within the core area of the Carpathian population (Hell \& Slamčka, 1996). Štiavnica is the largest volcanic complex in Slovakia, at 180-1,009 m altitude (Fig. 1). Two thirds of the Protected Landscape Area's $776 \mathrm{~km}^{2}$ are covered by deciduous and mixed forest; the remainder is a fragmented mosaic of meadows and agricultural land around human settlements, with a mean density of 63 persons per $\mathrm{km}^{2}$ (MPRV SR, 2014). Velká Fatra National Park is located c. $26 \mathrm{~km}$ north of Štiavnica. Mixed and coniferous forests cover 90\% of its $665 \mathrm{~km}^{2}$, with alpine meadows above the timberline. Human settlements are located on the periphery of the Park and the mean density is 10 people per $\mathrm{km}^{2}$ (MPRV SR, 2014). The topography is largely mountainous, at 400-1,592 $\mathrm{m}$ altitude. Both areas are included in the Natura 2000 network of protected areas of the EU Habitats Directive (49.7\% of the Protected Landscape Area and $72.7 \%$ of the National Park).

Several Carnivora besides lynx are present in both areas, including brown bears Ursus arctos and wildcats Felis silvestris, and grey wolves Canis lupus are present in Velká Fatra. Three species of native ungulates are common: red deer Cervus elaphus, roe deer Capreolus capreolus and wild boar Sus scrofa. There are also introduced fallow deer Dama dama and mouflon Ovis musimon in Štiavnica, and Alpine chamois Rupicapra rupicapra in Velká Fatra. Timber harvesting and hunting are permitted across most of both areas.

\section{Methods}

\section{Pilot surveys}

To enhance the probability of photographing and identifying lynx during capture-recapture surveys, we conducted pilot surveys of $1.5-2.5$ years' duration in each study area. The choice of study areas and camera-trap sites was based on information resulting from snow tracking as well as from observations (e.g. lynx sightings, tracks, prey remains) provided by our monitoring network of four rangers and 90

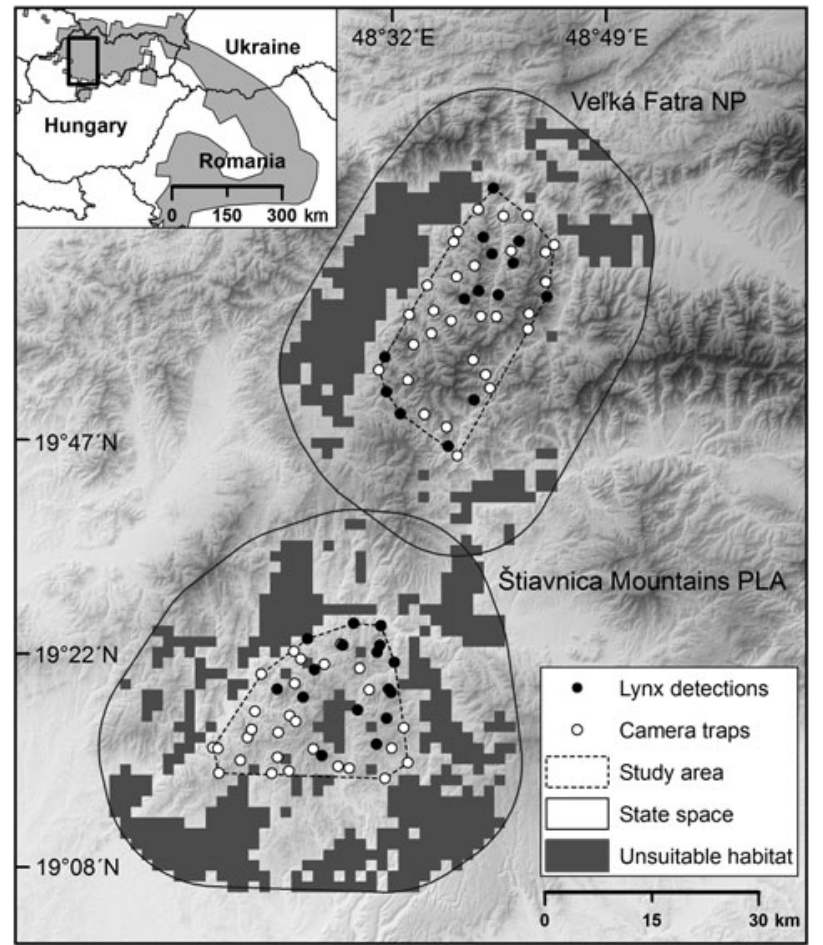

FIG. 1 Location of camera-trap stations in (a) Štiavnica Mountains Protected Landscape Area (PLA) and (b) Velká Fatra National Park (NP) in the Carpathian Mountains of central Slovakia. Mean convex polygons were enlarged by buffers of 16 and $14 \mathrm{~km}$, respectively, resulting in state-spaces in which we distinguished unsuitable (shaded) from suitable habitat fragments for the Eurasian lynx Lynx lynx. The shaded area in the inset shows the lynx's distribution in the Carpathian Mountains (Kaczensky et al., 2013).

registered hunters/foresters in Štiavnica and six rangers and 70 hunters/foresters in Velká Fatra. Beginning in 2011 in Štiavnica and 2013 in Velká Fatra, various models of digital camera were deployed throughout the year along forest roads, hiking paths, game trails and mountain ridges, as well as at lynx marking sites and kills (Zimmermann et al., 2007).

\section{Capture-recapture surveys}

Winter and early spring, before and during the lynx mating season, has been identified as the best period to conduct systematic camera trapping because of biological (i.e. high lynx activity), logistical (i.e. reduced human disturbance), and environmental factors (Zimmermann \& Foresti, 2016). Given the limited availability of cameras, in Štiavnica we used an adjacent block sampling design (Karanth \& Nichols, 2002): the western portion of the study area was surveyed during 6 January- 6 March, and the eastern block during 16 March-14 May 2014. In Velká Fatra we surveyed the whole study area simultaneously during 4 December 2014-2 February 2015. 
We used a $2.5 \times 2.5 \mathrm{~km}$ grid to distribute cameras, placing them in every second cell (Zimmermann et al., 2013). We excluded cells with unsuitable lynx habitat, such as agricultural land, human settlements and alpine meadows (15.6\% of Štiavnica, $5.2 \%$ of Velká Fatra), and placed cameras in adjacent cells (Weingarth et al., 2012). A total of 44 cells in Štiavnica and 43 in Velká Fatra were thus selected.

In each selected cell a camera station was established, consisting of a pair of cameras (M-88o infrared, Moultrie, Alabaster, USA; Ambush white flash, Cuddeback, Green Bay, USA) positioned to obtain images of both flanks of animals passing between them. Camera stations were located where lynx activity was recorded during the pilot surveys and at other locations considered to have most potential to obtain images of lynx. Because of their multiple disadvantages, no attractants were used to entice animals to camera traps (Zimmermann \& Foresti, 2016). Each camera was protected in a metal box secured to a tree with steel cable and camouflaged using netting, branches, lichen or other material. Cameras, set to detect motion 24 hours per day, were checked every 7-14 days, depending on weather conditions, to download data, replace batteries, clear snow or debris and readjust camera positioning as necessary.

\section{Identification of individuals}

We followed the procedure described in Zimmermann \& Foresti (2016) to distinguish individual lynx. Photographs of insufficient quality for confident identification were excluded from further analysis. An individual was identified as male if its scrotum was visible and as female if it was accompanied by one or more juveniles or, more rarely, if the genital area was clearly visible.

\section{Statistical analyses}

We divided each 6o-day survey into 12 sampling occasions of 5 consecutive days each. Multiple records of the same individual at the same location during the same sampling occasion were treated as a single capture event (Zimmermann et al., 2007; Weingarth et al., 2012; Avgan et al., 2014). Juveniles accompanying their mothers were excluded from analysis because of their high mortality and dispersal rates (Zimmermann et al., 2007). We tested whether sampled populations were closed, using CloseTest (Stanley \& Burnham, 1999; Stanley \& Richards, 2004).

Lynx densities were estimated by means of spatial capture-recapture analysis using the SPACECAP package (Singh et al., 2010) in $R$ v. 1.1.o (R Development Core Team, 2013). SPACECAP uses capture histories in combination with spatial locations of captures under a unified Bayesian modelling framework to compute density (Royle et al., 2009a,b). Three required input files were prepared:
(1) lynx capture details; (2) trap deployment dates when specific cameras were active; and (3) potential home-range centres. For the SPACECAP analysis we used the $\mathrm{M}_{\mathrm{o}}$ (null) model, half-normal detection and Bernoulli's encounter process. We ran the model with three Monte Carlo Markov chains with 80,000 iterations, a burn-in of 40,000 and a thinning rate of 3 . Bayesian analysis of the model was conducted using data augmentation by increasing the data set with 100 all-zero encounter histories (Royle et al., 2007).

We assessed model adequacy in SPACECAP by following the procedure described in Braczkowski et al. (2016). To find the minimum buffer width for which density estimates began to stabilize, we created a series of state-spaces with buffers of $2-24 \mathrm{~km}$ around the minimum convex polygon encompassing all camera traps (Pesenti \& Zimmermann, 2013). The total area of this minimum convex polygon was $431.9 \mathrm{~km}^{2}$ in Štiavnica and $489.1 \mathrm{~km}^{2}$ in Velká Fatra. Spatial density estimates decreased with increasing buffer width, stabilizing at a width of $16 \mathrm{~km}$ in Štiavnica and $14 \mathrm{~km}$ in Velká Fatra; these buffer widths were retained in the subsequent analyses. The state-space was thus described as a grid of 1,131 equally spaced potential homerange centres $(1.5 \times 1.5 \mathrm{~km})$ in Štiavnica and 1,066 in Velká Fatra, corresponding to areas of $2,544.75$ and $2,398.5 \mathrm{~km}^{2}$, respectively (Fig. 1).

To compare our results with earlier studies we also estimated abundance and density based on conventional capture-recapture models, using MARK 5.1 (White \& Burnham, 1999). The CAPTURE module tests several models that differ in their assumed sources of variation in encounter probability, including constant encounter probability $\left(\mathrm{M}_{\mathrm{o}}\right)$, variation among individuals $\left(\mathrm{M}_{\mathrm{h}}\right)$, variation across occasions $\left(\mathrm{M}_{\mathrm{t}}\right)$ and responses to previous encounters $\left(M_{b}\right)$. Subsequently, the best model can be selected from a set of eight closed-population models $\left(\mathrm{M}_{\mathrm{o}}\right.$, $M_{h}, M_{t}, M_{b}, M_{b h}, M_{t h}, M_{t b}$ and $M_{t b h}$; Otis et al., 1978). To obtain the effective sampled area we applied two measures, the mean maximum distance moved (MMDM) and $1 / 2$ MMDM, often used in studies of elusive felids as a buffer around the mean convex polygon encompassing all cameratrap sites (Pesenti \& Zimmermann, 2013). We used the delta method to calculate variance of density estimates (Karanth \& Nichols, 1998).

For both spatial and non-spatial capture-recapture analyses, lynx densities were estimated per $100 \mathrm{~km}^{2}$ of suitable habitat. Proportions of suitable and unsuitable habitats were derived from CORINE Land Cover 2012 (Copernicus Programme, 2012) with resolution of $100 \times 100 \mathrm{~m}$ in ArcMap 10.3 (ESRI, Redlands, USA). All types of forest (deciduous, coniferous and mixed), together with shrub and grasslands, were considered suitable habitat for lynx, whereas agricultural land and human settlements were excluded (Fig. 1). For spatial capture-recapture analyses, potential activity centres within (1) and outside (o) fragments of suitable 
lynx habitat were provided directly in the input matrix of potential home-range centres. We identified 711 centres $\left(1,599.75 \mathrm{~km}^{2}\right)$ within fragments of suitable lynx habitat in Štiavnica, and $820\left(1,845.0 \mathrm{~km}^{2}\right)$ in Velká Fatra. Similarly, for non-spatial capture-recapture analyses we excluded unsuitable habitat from the effective sampled area.

\section{Results}

\section{Pilot surveys}

In Štiavnica a total of 186 photographic records of lynx were obtained during 2011-2014 from 14 of 69 camera locations (20.3\%). We discarded 32 (17.2\%) photographs because they were of insufficient quality. Fifteen independent individuals (adults and subadults) and eight juveniles were identified ( 5 female, 10 male, 8 unknown). In Velká Fatra during 2013-2014 a total of 37 photographs of lynx were obtained from 8 of 31 locations (25.8\%), of which 12 (32.4\%) were discarded. We identified six independent individuals and two juveniles (2 female, 4 male, 2 unknown).

\section{Capture-recapture surveys}

All cameras were active throughout the whole 6o-day period in both areas except one station in Štiavnica that was stolen. Trapping effort was therefore $99.6 \%(2,630$ effective trap days) in Štiavnica and $100 \%$ in Velká Fatra $(2,580$ trap days). A total of 18,653 photographs were obtained in Štiavnica and 9,089 in Velká Fatra, of which $269(1.4 \%)$ and $100(1.1 \%)$, respectively, were of lynx (Table 1). Four photographs of lynx in each area were excluded from analyses because they were of insufficient quality ( $1.5 \%$ of lynx photographs in Štiavnica and $4.0 \%$ in Velká Fatra). Non-target wildlife species accounted for $64.6 \%(n=12,040)$ of photographs in Štiavnica and 69.9\% $(\mathrm{n}=6,354)$ in Vel'ká Fatra. The red deer was the most frequently detected species in both areas (Table 1). Empty images (i.e. no visible animals or people) accounted for $24.3 \%(n=4,527)$ of all photographs in Štiavnica and $17.2 \%(n=1,567)$ in Velká Fatra.

During the capture-recapture surveys there were 30 lynx detections at 16 of 44 camera stations (36.4\%) in Štiavnica, including seven independent individuals ( 3 female, 4 male), and 20 detections at 14 of 43 camera stations (32.6\%) in Velká Fatra, representing seven individuals (2 female, 3 male, 2 unknown). The closure test supported the assumption of population closure in Velká Fatra $\left(\chi^{2}=4.97\right.$; $\mathrm{df}=8$; $\mathrm{P}=0.76)$ but not in Štiavnica $\left(\chi^{2}=25.59 ; \quad \mathrm{df}=10\right.$; $\mathrm{P}=0.00434)$.

In Štiavnica, the posterior mean baseline encounter rate $\lambda_{\mathrm{o}}$ (posterior $\mathrm{SD}$ ) was $0.101 \pm \mathrm{SD} 0.028$ and the posterior mean movement parameter $\sigma$ (posterior SD) was $6.42 \pm \mathrm{SD}$ $0.86 \mathrm{~km}$. In Velká Fatra, the figures were $0.033 \pm \mathrm{SD} 0.012$ and $5.47 \pm \mathrm{SD} 1.74 \mathrm{~km}$, respectively. Resulting mean posterior densities (posterior SD) were $0.58 \pm$ SD 0.13 independent lynx per $100 \mathrm{~km}^{2}$ of suitable habitat in Štiavnica and $0.81 \pm$ SD 0.29 in Velká Fatra (Table 2). Bayesian P values were 0.57 and 0.52 , respectively, suggesting model adequacy. Both the Geweke (values between -1.6 and 1.6) and Gelman-Rubin (shrink reduction factors for key parameters all $<1.1$ ) diagnostics indicated convergence for all models run in SPACECAP.

The model selection procedure in CAPTURE (MARK) rated the $\mathrm{M}_{\mathrm{o}}$ model as the most appropriate and $\mathrm{M}_{\mathrm{h}}$ as the next best model in Štiavnica and Velká Fatra. We used the $\mathrm{M}_{\mathrm{h}}$ model for abundance estimates for both study areas because of its robustness. As the heterogeneity model $\mathrm{M}_{\mathrm{h}}$ (jackknife) indicated ill-conditioned data, we had to rely on $\mathrm{M}_{\mathrm{h}}$ (Chao). The mean capture probability $(p)$ under $\mathrm{M}_{\mathrm{h}}$ (Chao) was 0.241 in Štiavnica and 0.214 in Velká Fatra. The respective non-spatial capture-recapture abundance estimates were $9 \pm$ SE 3.74 independent lynx in Štiavnica and $7 \pm$ SE 0.54 in Velká Fatra. In Štiavnica, MMDM and $1 / 2 \mathrm{MMDM}$ were $6.4 \pm \mathrm{SE} 1.30 \mathrm{~km}$ and $3.2 \pm \mathrm{SE} 0.65 \mathrm{~km}$, respectively, and in Velká Fatra the corresponding values were $8.0 \pm S E 1.30 \mathrm{~km}$ and $4.0 \pm S E 0.65 \mathrm{~km}$. The resulting density estimates in Štiavnica were $1.11 \pm$ SE 0.47 independent lynx per $100 \mathrm{~km}^{2}$ of suitable habitat using MMDM, and $1.49 \pm \mathrm{SE} 0.64$ using $1 / 2 \mathrm{MMDM}$. The corresponding figures in Velká Fatra were $0.61 \pm$ SE 0.10 independent lynx per $100 \mathrm{~km}^{2}$ of suitable habitat using MMDM, and $0.84 \pm$ SE0.09 using $1 \frac{1}{2}$ MMDM (Table 3).

\section{Discussion}

Camera-trapping surveys with capture-recapture analysis are an efficient option for monitoring elusive species such as the lynx (e.g. Rovero \& Zimmermann, 2016). Our estimates of lynx population density based on spatially explicit capture-recapture models are the lowest reported so far for the Eurasian lynx. In the north-western Swiss Alps, posterior mean densities (posterior SD) of $1.47 \pm \mathrm{SD} 0.25$ and 1.38 \pm SD 0.23 individuals per $100 \mathrm{~km}^{2}$ of suitable habitat were estimated (Pesenti \& Zimmermann, 2013), and in Ciglikara Nature Reserve, Turkey, density (posterior SD) was estimated to be $4.2 \pm$ SD 2.0 individuals per $100 \mathrm{~km}^{2}$ (Avgan et al., 2014). Similarly, our density estimates based on non-spatial capture-recapture are among the lowest reported in similar habitats. The north Jura Mountains of Switzerland and the Bavarian Forest in Germany were found to have 1.13 and 0.9 lynx per $100 \mathrm{~km}^{2}$ of suitable habitat and all habitat, respectively (Zimmermann et al., 2007; Weingarth et al., 2012).

Our results may represent a population low, as lynx abundance and density may fluctuate over time, depending on ecological (e.g. prey base) and human-induced (e.g. 
TABLE 1 Species detected during capture-recapture surveys for the Eurasian lynx Lynx lynx in Štiavnica Mountains and Velká Fatra National Park, Slovakia (Fig. 1), during 2014-2015, with number of photographs, percentage of total photographs in each area, and percentage of photographs of non-target (NT) species.

\begin{tabular}{|c|c|c|c|c|c|c|}
\hline \multirow[b]{2}{*}{ Species } & \multicolumn{3}{|l|}{ Štiavnica (2014) } & \multicolumn{3}{|c|}{ Vel'ká Fatra (2014/15) } \\
\hline & No. of photographs & $\%$ & $\% \mathrm{NT}$ & Photographs & $\%$ & $\% \mathrm{NT}$ \\
\hline \multicolumn{7}{|l|}{ Ungulates } \\
\hline Red deer Cervus elaphus & 3,836 & 20.57 & 31.86 & 3,475 & 38.23 & 54.68 \\
\hline Wild boar Sus scrofa & 2,372 & 12.72 & 19.70 & 870 & 9.58 & 13.68 \\
\hline Roe deer Capreolus capreolus & 1,691 & 9.07 & 14.04 & 374 & 4.12 & 5.90 \\
\hline Fallow deer Dama dama & 117 & 0.63 & 0.97 & & & \\
\hline Mouflon Ovis musimon & 61 & 0.33 & 0.51 & & & \\
\hline Chamois Rupicapra rupicapra & & & & 13 & 0.14 & 0.20 \\
\hline \multicolumn{7}{|l|}{ Large carnivores } \\
\hline Eurasian lynx Lynx lynx & 269 & 1.44 & & 100 & 1.10 & \\
\hline Brown bear Ursus arctos & 23 & 0.12 & 0.19 & 160 & 1.76 & 2.52 \\
\hline Grey wolf Canis lupus & & & & 38 & 0.42 & 0.56 \\
\hline \multicolumn{7}{|l|}{ Other carnivores } \\
\hline Red fox Vulpes vulpes & 1,723 & 9.24 & 14.31 & 1,192 & 13.11 & 18.76 \\
\hline Badger Meles meles & 950 & 5.09 & 7.89 & 52 & 0.57 & 0.82 \\
\hline Wildcat Felis silvestris & 466 & 2.50 & 3.87 & 10 & 0.11 & 0.19 \\
\hline Martens Martes sp. & 437 & 2.34 & 3.63 & 60 & 0.66 & 0.94 \\
\hline Domestic cat Felis catus & 81 & 0.43 & 0.67 & & & \\
\hline Domestic dog Canis familiaris & 51 & 0.27 & 0.42 & 13 & 0.14 & 0.21 \\
\hline Steppe polecat Mustela eversmanii & 2 & 0.01 & 0.02 & & & \\
\hline \multicolumn{7}{|l|}{ Other species } \\
\hline Brown hare Lepus europaeus & 135 & 0.72 & 1.12 & 91 & 1.00 & 1.42 \\
\hline Red squirrel Sciurus vulgaris & 79 & 0.42 & 0.66 & 1 & 0.01 & 0.02 \\
\hline European hedgehog Erinaceus europaeus & 16 & 0.09 & 0.13 & & & \\
\hline Hazel grouse Bonasa bonasia & & & & 5 & 0.06 & 0.10 \\
\hline People & 1,817 & 9.74 & & 1,068 & 11.75 & \\
\hline Empty images & 4,527 & 24.27 & & 1,567 & 17.24 & \\
\hline Total & 18,653 & & & 9,089 & & \\
\hline
\end{tabular}

hunting, poaching) factors. For example, 3 -fold changes in lynx density were observed in the Swiss Jura Mountains (Zimmermann et al., 2009, 2015), and 1.6-fold in the northwestern Alps (Zimmermann et al., 2014, 2016). However, as our results are the first robust estimates of lynx density in Slovakia we cannot assess population trends or fluctuations until the surveys are repeated in the future.

There are several other factors that may account for the relatively low lynx densities in our study areas, including technical (e.g. camera-trap failures), conceptual (e.g. population closure violation, suboptimal sampling period), ecological (e.g. lower carrying capacity, habitat alteration or fragmentation, inbreeding, reduced fitness and interspecific competition) and human-related factors (human-induced mortality). Here we discuss the most relevant issues.

The large number of empty images we obtained is probably attributable to the high sensitivity of infrared cameras to moving objects (e.g. birds, snow) rather than equipment failures. Our cameras worked well throughout the 5,210 trap days of our two surveys and we achieved an effective trapping effort of $99.8 \%$. For comparison, previous studies of the Eurasian lynx carried out using the same methodology achieved $84-99.6 \%$ in Switzerland (Zimmermann et al., 2016), 98\% in Germany (Weingarth et al., 2012) and 99\% in Turkey (Avgan et al., 2014).

Violation of the population closure assumption in Štiavnica may have been influenced by the longer duration of the survey because of the adjacent block sampling design, which may explain the high proportion of lynx detected only once. However, all detected individuals had already been identified during the pilot survey and we have no evidence of immigration during the capture-recapture survey. Juveniles start dispersal in early spring, but they were not included in our estimates. Although our survey in Štiavnica covered a 4-month period and ended slightly later in the year (mid May) compared to the Velká Fatra survey and other capture-recapture studies of lynx (e.g. Pesenti \& Zimmermann, 2013), we do not think that this could have had a strong impact on mean density estimates.

Another reason for low lynx densities could be that the Slovak Carpathians may have a lower carrying capacity than other study sites. However, the Slovak Carpathians are thought to provide excellent conditions for lynx because they have a high proportion of forest cover (the main habitat 
TABLE 2 Posterior summaries of the SPACECAP parameters for the camera-trapping surveys in Štiavnica Mountains and Velká Fatra National Park, Slovakia (Fig. 1), during 2014-2015, with area of suitable habitat, numbers of suitable and unsuitable centres, area of state-space, encounter rate $(\lambda \mathrm{o})$, movement parameter $(\sigma)$, estimated mean lynx population size, and estimated mean density per $100 \mathrm{~km}^{2}$ of suitable habitat.

\begin{tabular}{lll}
\hline & $\begin{array}{l}\text { Śtiavnica } \\
(2014)\end{array}$ & $\begin{array}{l}\text { Vel'ká Fatra } \\
(2014 / 2015)\end{array}$ \\
\hline $\begin{array}{l}\text { Suitable habitat }\left(\mathrm{km}^{2}\right)^{1} \\
\begin{array}{l}\text { No. of suitable/unsuitable } \\
\text { centres }\end{array}\end{array}$ & $\begin{array}{l}1,599.75 \\
711 / 420\end{array}$ & $\begin{array}{l}1,845.0 \\
820 / 246\end{array}$ \\
$\begin{array}{l}\text { State-space }\left(\mathrm{km}^{2}\right)^{2} \\
\text { Encounter rate, } \lambda 0 \\
\quad(\text { mean } \pm \text { SD) }\end{array}$ & $2,544.75$ & $2,398.5$ \\
$\begin{array}{l}\text { Movement parameter, } \sigma, \mathrm{km} \\
(\text { mean } \pm \text { SD) }\end{array}$ & $0.101 \pm 0.028$ & $0.033 \pm 0.012$ \\
$\begin{array}{l}\text { Estimated lynx population } \\
\text { size (mean } \pm \text { SD) }\end{array}$ & $9.26 \pm 2.02$ & $15 \pm 5.27$ \\
$\begin{array}{l}\text { Estimated density, lynx per } \\
\quad \begin{array}{l}\text { 100 km } \\
\text { (mean } \pm \text { Suitable habitat }\end{array}\end{array}$ & $0.58 \pm 0.13$ & $0.81 \pm 0.29$ \\
\hline
\end{tabular}

${ }^{1}$ Suitable habitat was determined from all types of forest (deciduous, coniferous and mixed) together with shrub and grasslands; agricultural land and human settlements were excluded.

${ }^{2}$ Both state-spaces were described as a grid of equally spaced $(1.5 \times 1.5 \mathrm{~km})$ potential home range centres, within and outside suitable habitat fragments.

${ }^{3}$ Density was calculated by dividing the estimated population size by the area of the state-space within suitable habitat.

of lynx in Europe; Breitenmoser \& Breitenmoser-Würsten, 2008). Wild ungulate populations are at a historical maximum, causing substantial browsing damage to forests and crops (Konôpka \& Kaštier, 2014). We therefore consider it unlikely that lynx density in our study areas was limited by carrying capacity compared to other European ecoregions at the same latitude.

Low lynx densities may also be a result of humaninduced mortality. In general, the main causes of mortality in adult Eurasian lynx in human-dominated landscapes, even protected areas, are anthropogenic (von Arx et al., 2004; Andrén et al., 2006), particularly vehicle collisions and poaching (Stahl \& Vandel, 1999; Schmidt-Posthaus et al., 2002; Magg et al., 2016; Sindičić et al., 2016). During our study there was apparently a high population turnover. Although we detected 23 individuals ( 15 adult, 8 juvenile) during the pilot survey in Štiavnica in 2011-2014, only $20 \%$ were recaptured later. The mean persistence of lynx in Štiavnica was only $\mathbf{1 2 . 7}$ months (range 2-23 months). Of the eight individuals ( 6 adult, 2 juvenile) we identified in Velká Fatra during the pilot survey, only three were detected during the capture-recapture survey. We know of two lynx in Štiavnica and one in Vel'ká Fatra killed by vehicles during our study. Considering the occurrence of apparently orphaned lynx in Slovakia (39 known cases during 2001-2015; B. Tám, Bojnice Zoo, pers. comm.), as well as lynx killed illegally (7 known cases during 2001-2014, of which one was detected in Štiavnica; E. Gregorová, Bojnice Zoo, pers. comm.), we suspect a high rate of adult mortality in the population. In our view, undiscovered anthropogenic mortality is the most likely explanation for the observed low lynx densities and high population turnover.

Official game statistics in Slovakia purport to show strong lynx population growth following the cessation of hunting in 2000, reaching 1,668 individuals in 2014 (NLC, 2015; Fig. 2). However, the veracity of these figures and validity of the methodology used to collect these data, particularly for wide-ranging species such as large carnivores, have been called into doubt by numerous authors (e.g. Hell \& Slamečka, 1996; Okarma et al., 2000). Hunters report numbers of game species in hunting grounds throughout Slovakia, which are then simply summed at the National Forest Centre to derive estimates of abundance. However, these numbers are guesstimates based on lynx sightings, tracks and prey remains recorded sporadically by hunters throughout the year. Moreover, hunting grounds are considerably smaller $\left(\right.$ mean $\left.=26 \mathrm{~km}^{2}\right)$ than lynx home ranges (e.g. median $=283 \mathrm{~km}^{2}$ for males and $185 \mathrm{~km}^{2}$ for females in similar habitats of the Swiss Jura Mountains; Breitenmoser-Würsten et al., 2007), which results in multiple counting of the same individuals, and subsequent overestimation of population size. According to official game statistics in both state-spaces there were 52 lynx in Štiavnica and 104 in Velká Fatra, at densities of 3.3 and 5.6 per $100 \mathrm{~km}^{2}$, respectively (i.e. $6-7$ times higher than our spatial capture-recapture estimates).

The reports of 300-400 lynx made by the Slovak authorities to the European Commission on the status of species protected by the Habitats Directive (Černecký et al., 2014) for the periods 2004-2006 and 2007-2012 were not based on scientifically robust data, as no systematic monitoring was implemented (Kaczensky et al., 2013; Černecký et al., 2014). Contrary to the declaration of Černecky et al. (2014), the approach did not include any modelling and we believe that it may simply be a repetition of old expert estimates (e.g. Salvatori et al., 2002; von Arx et al., 2004) based on lynx sightings, track counts, unspecific surveys, inquiries, and known mortality. Using the mean lynx density we calculated by means of spatial capture-recapture (0.70 individuals per $100 \mathrm{~km}^{2}$ of suitable habitat) we estimate there are c. $197 \pm$ SE 56 independent lynx in the $28,090 \mathrm{~km}^{2}$ of occupied range (Kaczensky et al., 2013) in Slovakia.

Our results indicate not only that lynx abundance in Slovakia is likely to be markedly lower than officially reported, but that the population may not be at favourable conservation status as required by the EU Habitats Directive. The thresholds for favourable conservation status at national level were defined as density of $\geq 1$ individuals 
TABLE 3 Lynx abundance and density per $100 \mathrm{~km}^{2}$ of suitable habitat in Štiavnica Mountains and Velká Fatra National Park estimated by means of the non-spatial heterogeneity model $M_{\mathrm{h}}$ (Chao). The effective sampled area was restricted to suitable lynx habitat fragments within the areas formed by the minimum convex polygons (MCP) encompassing all camera-trap sites enlarged with two buffer widths: mean maximum distance moved (MMDM) and $1 / 2 \mathrm{MMDM}$.

\begin{tabular}{|c|c|c|c|c|}
\hline \multirow[b]{2}{*}{ Method } & \multicolumn{2}{|c|}{ Štiavnica (2014) } & \multicolumn{2}{|c|}{ Velká Fatra (2014/2015) } \\
\hline & MMDM & $1 / 2 \mathrm{MMDM}$ & MMDM & $1 / 2 \mathrm{MMDM}$ \\
\hline $\mathrm{MCP}\left(\mathrm{km}^{2}\right)$ & 431.9 & 431.9 & 489.1 & 489.1 \\
\hline Abundance (mean $\pm \mathrm{SE})$ & $9 \pm 3.74$ & $9 \pm 3.74$ & $7 \pm 0.54$ & $7 \pm 0.54$ \\
\hline Buffer, km (mean \pm SE) & $6.4 \pm 1.30$ & $3.2 \pm 0.65$ & $8 \pm 1.30$ & $4 \pm 0.65$ \\
\hline Suitable habitat $\left(\mathrm{km}^{2}\right)$ & 812.3 & 603 & $1,145.3$ & 837 \\
\hline Density, lynx per $100 \mathrm{~km}^{2}$ suitable habitat (mean $\left.\pm \mathrm{SE}\right)$ & $1.11 \pm 0.47$ & $1.49 \pm 0.64$ & $0.61 \pm 0.10$ & $0.84 \pm 0.09$ \\
\hline
\end{tabular}
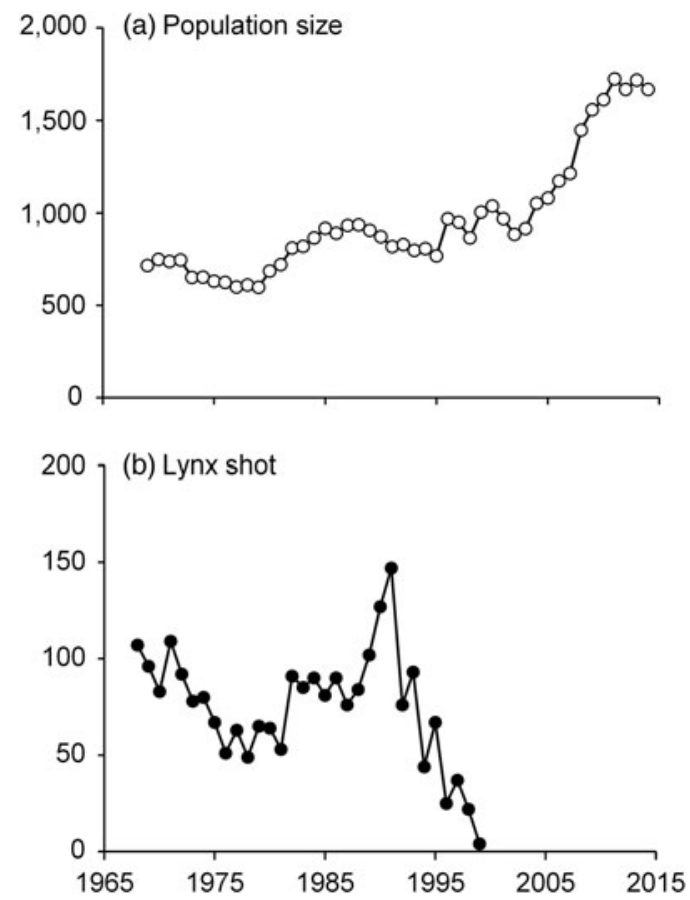

FIG. 2 (a) Lynx population size based on hunters' reports (e.g. lynx sightings, tracks and other field signs) from all hunting grounds throughout Slovakia, and (b) numbers of lynx legally shot during 1968-2014 according to official game statistics in Slovakia (after NLC, 2015).

per $100 \mathrm{~km}^{2}$ of main forest habitat, and population size of $\geq 250$ individuals in Slovakia (Kropil, 2005).

Although Slovakia reported having 300-400 lynx, the overall conservation status was declared to be unfavourable-inadequate because there were insufficient data to assess lynx range, population and habitat (Černecký et al., 2014). If a species is not at favourable conservation status, the responsible authorities are obliged to implement appropriate measures to improve the status of the species. Such actions should include implementation of a conservation programme based on a thorough understanding of population status and dynamics, including controlling factors and main threats and human dimensions such as attitudes and conflicts (Rigg et al., 2011). Other actions could aim to raise awareness of the species among hunters, foresters and the general public, involve interest groups in the monitoring and conservation of the species, and improve law enforcement for species and habitat protection.

Our results are the first robust estimates of lynx abundance and density in Slovakia. We do not know if they are representative of the whole population or the long-term mean density. However, as our study took place in comparatively well-managed protected areas, we assume our results are more likely to be above than below average for the population. We therefore call for continuous assessment of the density and trend of the Slovak Carpathian lynx population, and the establishment of a scientifically robust monitoring system. Beyond the opportunity to improve monitoring, we hope that renewed international interest in the lynx population in Slovakia will help raise awareness of the species and ensure that it has a higher priority on the agenda of wildlife managers, conservationists and researchers.

\section{Acknowledgements}

Our study formed part of the Living with Carpathian Spirits project, implemented by the Slovak Wildlife Society in partnership with KORA and Bojnice Zoo, financed by the Swiss-Slovak Cooperation Programme (PP-2013-007), with co-funding from the Slovak Wildlife Society, Die Karl Mayer Stiftung and the Wolves and Humans Foundation. The Technical University in Zvolen was supported by grant no. ITMS 26220120006 and VEGA 2/0077/17. We thank the many other institutions and individuals that contributed, particularly M. Apfelová, S. Betková, R. Čech, V. Madajová, L'. Remeník, R. Retkovský, J. Schestág and J. Žiak, as well as foresters, hunters, students and volunteers who assisted with fieldwork.

\section{Author contributions}

The study was conceived and designed by JK, PS, UB, CB-W, FZ, RR and RK. Fieldwork was coordinated by JK and RR, assisted by PS, TI and BT. JK, PS, FZ and DF 
performed statistical analyses. RK supervised the work of JK and PS. The article was written by JK, PS, UB, FZ and RR.

\section{References}

Andrén, H., Linnell, J.D.C., Liberg, O., Andersen, R., Danell, A., KARLSSON, J. et al. (2006) Survival rates and causes of mortality in Eurasian lynx (Lynx lynx) in multi-use landscapes. Biological Conservation, 131, 23-32.

Avgan, B., Zimmermann, F., Güntert, M., Arikan, F. \& Breitenmoser, U. (2014) The first density estimation of an isolated Eurasian lynx population in southwest Asia. Wildlife Biology, 20, 217-221.

Braczkowski, A.R., Balme, G.A., Dickman, A., Fattebert, J., Johnson, P., Dickerson, T. et al. (2016) Scent lure effect on camera-trap based leopard density estimates. PLoS One 11(4), e0151033.

Breitenmoser, U. \& Breitenmoser-Wúrsten, C. (2008) Der Luchs - ein Grossraubtier in der Kulturlandschaft. Salm Verlag, Bern, Switzerland.

Breitenmoser, U., Breitenmoser-Würsten, C., Okarma, H., Kaphegyi, T., Kaphegyi-Wallmann, U. \& Mueller, U.M. (2000) Action Plan for the Conservation of the Eurasian Lynx (Lynx lynx) in Europe. Council of Europe Publishing, Strasbourg, France.

Breitenmoser-Würsten, C. \& Obexer-Ruff, G. (2003) Population and conservation genetics of two reintroduced lynx (Lynx lynx) populations in Switzerland - a molecular evaluation 30 years after translocation. Environmental Encounters, 58, 51-55.

Breitenmoser-Wúrsten, C., Zimmermann, F., Molinari-Jobin, A., Molinari, P., Capt, S., Vandel, J.-M. et al. (2007) Spatial and social stability of a Eurasian lynx Lynx lynx population: an assessment of 10 years of observation in the Jura Mountains. Wildlife Biology, 13, 365-380.

Černecký, J., Galvánková, J., Považan, R., Saxa, A., Šeffer, J., Šmferová, V. et al. (2014) Conservation Status of Habitats and Species of Community Interest in the Period of 2007-2012 in the Slovak Republic. State Nature Conservancy of the Slovak Republic, Banská Bystrica, Slovakia.

Copernicus Programme (2012) CORINE Land Cover 2012. Http:// land.copernicus.eu/pan-european/corine-land-cover/clc-2012.

Hell, P. \& SlameČKA, J. (1996) Current status of the lynx (Lynx lynx) in Slovakia. Acta Scientarum Naturalium Academiae Scientiarum Bohemicae Brno, 30, 64-78.

IUCN/SSC (2013) Guidelines for Reintroductions and Other Conservation Translocations. Version 1.o. IUCN Species Survival Commission, Gland, Switzerland.

Kaczensky, P., Chapron, G., von Arx, M., Huber, D., Andrén, H. \& Linnell, J. (eds) (2013) Status, Management and Distribution of Large Carnivores-Bear, Lynx, Wolf \& Wolverine-in Europe. Part 1: Europe Summaries. Large Carnivore Initiative for Europe Report to the European Commission.

Karanth, K.U. \& Nichols, J.D. (1998) Estimation of tiger densities in India using photographic captures and recaptures. Ecology, 79, 2852-2862.

Karanth, K.U. \& Nichols, J.D. (2002) Monitoring Tigers and Their Prey: A Manual for Wildlife Managers, Researchers and Conservationists in Tropical Asia. Centre for Wildlife Studies, Bangalore, India.

KONÔPKA, J. \& KAšTIER, P. (2014) Koncepcia rozvoja polovníctva v Slovenskej Republike. Polovnícke štúdie. Národné lesnícke centrum - Lesnícky výskumný ústav, Zvolen, Slovakia.
KROPIL, R. (2005) Definovanie priaznivého stavu živočíšnych druhov. Názov druhu: rys ostrovid (Lynx lynx). In Priaznivý stav biotopov a druhov európskeho významu (eds P. Polák \& A. Saxa), pp. 509-510. State Nature Conservancy of the Slovak Republic, Banská Bystrica, Slovakia.

Magg, N., Múller, J., Heibl, C., Hackländer, K., Wölfl, S., WölfL, M. et al. (2016) Habitat availability is not limiting the distribution of the Bohemian-Bavarian lynx Lynx lynx population. Oryx, 50, 742-752.

MPRV SR (2014) Slovakia Rural Development Programme (National). Ministry of Agriculture and Rural Development, Bratislava, Slovakia.

NLC (2015) Polovnícka štatistická ročenka SR 2014. Národné lesnícke centrum, Zvolen, Slovakia.

Okarma, H., Dovhanych, Y., Findo, S., Ionescu, O., Koubek, P. \& Szemethy, L. (200o) Status of Carnivores in the Carpathian Ecoregion. Carpathian Ecoregion Initiative Report.

Otis, D.L., Burnham, K.P., White, G.C. \& Anderson, D.R. (1978) Statistical inference from capture data on closed animal populations. Wildlife Monographs, 62, 1-135.

Pesenti, E. \& Zimmermann, F. (2013) Density estimations of the Eurasian lynx (Lynx lynx) in the Swiss Alps. Journal of Mammalogy, 94, 73-81.

R Development Core Team (2013) R: A Language and Environment for Statistical Computing. R Foundation for Statistical Computing, Vienna, Austria. Http://www.R-project.org/ [accessed 15 February 2015].

Rigg, R., Finďo, S., Wechselberger, M., Gorman, M.L., Sillero-Zubiri, C. \& Macdonald, D.W. (2011) Mitigating carnivore-livestock conflict in Europe: lessons from Slovakia. Oryx, 45, 272-280.

Rovero, F. \& Zimmermann, F. (2016) Introduction. In Camera Trapping for Wildlife Research (eds F. Rovero \& F. Zimmermann), pp. 1-7. Pelagic Publishing, Exeter, UK.

Royle, J.A., Dorazio, R.M. \& Link, W.A. (2007) Analysis of multinomial models with unknown index using data augmentation. Journal of Computational and Graphical Statistics, $16,67-85$.

Royle, J.A., Karanth, K.U., Gopalaswamy, A.M. \& Kumar, N.S. (2009a) Bayesian inference in camera trapping studies for a class of spatial capture-recapture models. Ecology, 90, 3233-3244.

Royle, J.A., Nichols, J.D., Karanth, K.U. \& Gopalaswamy, A.M. (2009b) A hierarchical model for estimating density in camera trap studies. Journal of Applied Ecology, 46, 118-127.

Salvatori, V., Okarma, H., Ionescu, O., Dovhanych, Y., Finďo, S. \& Boitani, L. (2002) Hunting legislation in the Carpathian Mountains: implications for the conservation and management of large carnivores. Wildlife Biology, 8, 3-10.

Schmidt-Posthaus, H., Breitenmoser-Würsten, C., Posthaus, H., Bacciarini, L. \& Breitenmoser, U. (2002) Causes of mortality in reintroduced Eurasian lynx in Switzerland. Journal of Wildife Diseases, 38, 84-92.

Schnidrig, R., Nienhuis, C., Imhof, R., Bürki, R. \& Breitenmoser, U. (2016) Lynx in the Alps: Recommendations for an Internationally Coordinated Management. RowAlps Report Objective 3. KORA Report No. 71. KORA, Bern, Switzerland.

Sindičić, M., Gomerčić, T., Kusak, J., Slijepčević, V., Huber, Đ. \& Frković, A. (2016) Mortality in the Eurasian lynx population in Croatia over the course of 40 years. Mammalian Biology, 81, 290294.

Sindičić, M., Polanc, P., Gomerčić, T., Jelenčič, M., Huber, Đ., Trontelj, P. \& Skrbinšek, T. (2013) Genetic data confirm critical status of the reintroduced Dinaric population of Eurasian lynx. Conservation Genetics, 14: 1009-1018. 
Singh, P., Gopalaswamy, A.M., Royle, J.A., Kumar, N.S. \& Karanth, K.U. (2010) SPACECAP: A Program to Estimate Animal Abundance and Density Using Spatially Explicit Capture-Recapture. R package v. 1.1.o. Http://cran.r-project.org/web/packages/ SPACECAP/index.html [accessed 7 July 2014].

Stahl, P. \& Vandel, J.M. (1999) Mortalité et captures de lynx (Lynx lynx) en France (1974-1998). Mammalia, 1, 49-59.

Stanley, T.R. \& Burnham, K.P. (1999) A closure test for time-specific capture-recapture data. Environmental and Ecological Statistics, 6, 197-209.

Stanley, T.R. \& Richards, J.D. (2004) Close Test Version 3.o, A Program for Testing Capture-Recapture Data for Closure. U.S. Geological Survey, Fort Collins Science Center, Colorado, USA.

von Arx, M., Breitenmoser-Würsten, C., Zimmermann, F. \& Breitenmoser, U. (2004) Status and Conservation of the Eurasian Lynx (Lynx lynx) in Europe in 2001. KORA Report No. 19e. KORA, Bern, Switzerland.

Weingarth, K., Heibl, C., Knauer, F., Zimmermann, F., Bufka, L. \& HeUrich, M. (2012) First estimation of Eurasian lynx (Lynx lynx) abundance and density using digital cameras and capture-recapture techniques in a German national park. Animal Biodiversity and Conservation, 35, 197-207.

White, G.C. \& Burnham, K.P. (1999) Program MARK: survival estimation from populations of marked animals. Bird Study, 46, 120-139.

Zimmermann, F., Breitenmoser-Würsten, C., Molinari-Jobin, A. \& Breitenmoser, U. (2013) Optimizing the size of the area surveyed for monitoring a Eurasian lynx (Lynx lynx) population in the Swiss Alps by means of photographic capture-recapture. Integrative Zoology, 8, 232-243.

Zimmermann, F., Fattebert, J., Breitenmoser-Würsten, C. \& Breitenmoser, U. (2007) Abundanz und Dichte der Luchse Fang-Wiederfang-Schätzung mittels Fotofallen im nördlichen Schweizer Jura. KORA Report No. 37d. KORA, Bern, Switzerland.

Zimmermann, F. \& Foresti, D. (2016) Capture-recapture methods for density estimation. In Camera Trapping for Wildlife Research (eds F. Rovero \& F. Zimmermann), pp. 95-141. Pelagic Publishing, Exeter, UK.
Zimmermann, F., Foresti, D., Bach, J., Dulex, N., Breitenmoser-Würsten, C. \& Breitenmoser, U. (2014) Abundanz und Dichte des Luchses in den Nordwestalpen: Fang-Wiederfang-Schätzung mittels Fotofallen im K-VI im Winter 2013/14. KORA Report No. 64. KORA, Bern, Switzerland.

Zimmermann, F., Hebeisen, C., Eichholzer, A., Theus, M., Breitenmoser-Wúrsten, C. \& Breitenmoser, U. (2009) Abondance et densité du lynx dans le Sud du Jura suisse: estimation par capture-recapture phototraphique dans le C-I durant l'hiver 2008/09. KORA Report No. 47. KORA, Bern, Switzerland.

Zimmermann, F., Kunz, F., Foresti, D., Asselain, M., Ravessoud, T., Schwenr, P. et al. (2015) Abondance et densité du lynx dans le Sud du Jura suisse: estimation par capture-recapture phototraphique dans le comparitment I durant l'hiver 2014/15. KORA Report No. 69. KORA, Bern, Switzerland.

Zimmermann, F., Kunz, F., Rhein, K., Shepherd, M., Tschanz, P., Breitenmoser-Würsten, C. \& Breitenmoser, U. (2016) Abundanz und Dichte des Luchses in den Nordwestalpen: Fang-Wiederfang-Schätzung mittels Fotofallen im K-VI im Winter 2015/16. KORA Report No. 73. KORA, Bern, Switzerland.

\section{Biographical sketches}

Jakub Kubala's research focuses on lynx ecology. Peter Smolko's work is focused on predator-prey relationships in large mammals. FRIDOLIN ZIMMERMANN coordinates monitoring of large carnivores in Switzerland and is an expert in camera trapping. RoBIN RIGG has led work on large carnivore conservation and research at the Slovak Wildlife Society since its founding in 1998. BR ANISLAV TÁm is curator of ungulates, elephants and carnivores at Bojnice Zoo. To MÁš IL KO has studied the pelage of the Carpathian lynx. Danilo Foresti specializes in monitoring and habitat modelling. CHRISTINe BREITENMOSER-WÚRSTEN is programme coordinator and administrative director of KORA and co-chair of the IUCN SSC Cat Specialist Group. RUdolf KROPIL's research focuses on mammal and bird ecology. URS BREITENMOSER is director of KORA and cochair of the IUCN SSC Cat Specialist Group. 